\title{
Elevated expression of CTRP3/cartducin contributes to promotion of osteosarcoma cell proliferation
}

\author{
HIRONORI AKIYAMA ${ }^{1,2}$, SOUHEI FURUKAWA ${ }^{2}$, SATOSHI WAKISAKA ${ }^{1}$ and TAKASHI MAEDA ${ }^{1}$ \\ Departments of ${ }^{1}$ Anatomy and Cell Biology, and ${ }^{2}$ Radiology, Graduate School of Dentistry, \\ Osaka University, Suita, Osaka 565-0871, Japan
}

Received October 2, 2008; Accepted December 9, 2008

DOI: $10.3892 /$ or_00000377

\begin{abstract}
CTRP3/cartducin, a novel secretory protein, is a member of the C1q and tumor necrosis factor (TNF)-related protein (CTRP) superfamily, and plays important roles in regulating both embryonic cartilage development and postnatal longitudinal bone growth. CTRP3/cartducin is expressed in human osteosarcomas. We hypothesized that CTRP3/cartducin might have a role in osteosarcoma tumor growth and metastasis. Murine osteosarcoma cell lines, NHOS and LM8, were used as a model. RT-PCR analysis showed that the mRNA level of CTRP3/cartducin was increased in these two murine osteosarcoma cell lines compared with its level in normal murine osteoblast MC3T3-E1 cells. Western blot analysis showed that the protein level of CTRP3/cartducin was also increased in these two osteosarcoma cell lines. Stimulation of NHOS and LM8 cells by CTRP3/cartducin promoted tumor cell growth but not migration in vitro. Further, CTRP3/ cartducin stimulation led to the activation of extracellular signal-regulated kinase 1/2 (ERK1/2) in these two osteosarcoma cell lines. MAPK/ERK kinase 1/2 (MEK1/2) inhibitor, U0126, blocked CTRP3/cartducin-induced cell proliferation. These results suggest that CTRP3/cartducin expression may play a role in osteosarcoma tumor growth associated with activation of the ERK1/2 signaling pathway.
\end{abstract}

\section{Introduction}

Osteosarcoma is the most common primary malignant bone tumor in both children and adults. It accounts for $\sim 60 \%$ of malignant bone tumors diagnosed in the first two decades of life. Although major advances in the treatment of this cancer have been achieved during recent decades, $30-40 \%$ of patients still experience relapses and an adverse outcome (1).

A new highly conserved family of adiponectin paralogs has been designated $\mathrm{C} 1 \mathrm{q}$ and tumor necrosis factor (TNF)-related

Correspondence to: Dr Takashi Maeda, Department of Anatomy and Cell Biology, Graduate School of Dentistry, Osaka University, 1-8 Yamadaoka, Suita, Osaka 565-0871, Japan

E-mail: tmaeda@dent.osaka-u.ac.jp

Key words: CTRP3/cartducin, osteosarcoma, proliferation, mitogen activated protein kinase proteins (CTRPs). There are seven members in the CTRP family and the proteins in this family exhibit similar structural organization to adiponectin and consist of four distinct domains including an $\mathrm{N}$-terminal signal peptide, a short variable domain, a collagen-like domain, and a C-terminal C1q-like globular domain $(2,3)$. While structurally related, members of this protein family are functionally diverse. CTRP1 is known to be expressed in the vascular wall tissues and to inhibit collagen-induced platelet aggregation by blocking von Willebrand factor binding to collagen (4). CTRP2 has been reported to induce the phosphorylation of AMP-activated protein kinase, resulting in increased glycogen accumulation and fatty acid oxidation (3). CTRP5 is localized to the lateral and apical membranes of the retinal pigment epithelium and ciliary body, and mutation of the CTRP5 gene is associated with late-onset retinal degeneration (5).

CTRP3/cartducin is a growth plate cartilage-derived secretory protein first identified during a search for the genes underlying the induction of chondrocyte differentiation. We showed that this molecule is a novel growth factor that plays important roles in regulating both chondrogenesis and cartilage development (6-8). The CTRP3/cartducin gene was also found in a screen for differentially expressed genes in a balloon-injured rat carotid artery model. It was transiently upregulated in injured artery tissue during a period characterized by neointima formation (9). Stimulation with CTRP3/cartducin in endothelial cells promotes proliferation and migration in these cells (10). Accumulating evidence supports that tissue repair and carcinogenesis are tightly linked (11-13). To date, no investigation has addressed the roles of CTRP3/cartducin in cancer despite a recent study showing its gene expression in osteosarcoma, chondrosarcoma and giant cell tumors (14).

In the present study, we hypothesized that CTRP3/cartducin had direct effects on osteosarcoma cells, which would enhance tumor growth and metastasis in osteosarcoma. We also examined the possible signaling pathways involved in CTRP3/ cartducin action on osteosarcoma cells.

\section{Materials and methods}

Reagents. Mouse recombinant CTRP3/cartducin was prepared as described (7). Anti-mouse CTRP3/cartducin antibody was purchased from R\&D Systems (Minneapolis, MN). AntiERK1/2 and anti- $\beta$-actin antibodies were purchased from 
Sigma-Aldrich (St. Louis, MO). Anti-phospho-ERK1/2 (p-ERK1/2) antibody was purchased from Cell Signaling Technology, Inc. (Beverly, MA). MEK1/2 inhibitor U0126 was purchased from Calbiochem (San Diego, CA).

Cell lines and cell culture. The osteoblast-like cell line MC3T3-E1 was maintained in $\alpha$-minimal essential medium ( $\alpha$-MEM) (Sigma-Aldrich) supplemented with 10\% FCS (PAA Laboratories, Linz, Austria). The mouse osteosarcoma cell line NHOS was first established from a spontaneous soft tissue tumor in a BALB/c mouse (15), and maintained in RPMI-1640 supplemented with $10 \%$ FCS. The mouse osteosarcoma cell line LM8 was established from Dunn's osteosarcoma (16), and maintained in minimal essential medium (MEM) (SigmaAldrich) supplemented with $10 \%$ FCS. These two murine osteosarcoma cell lines and MC3T3-E1 normal murine osteoblasts were obtained from RIKEN BioResource Center (Ibaraki, Japan). All cells were incubated at $37^{\circ} \mathrm{C}$ in a humidified atmosphere containing $5 \% \mathrm{CO}_{2}$. To investigate the effects of cartducin on mitogen-activated protein kinase (MAPK) signaling pathways, the cells were seeded at a density of $1 \times 10^{4}$ cells/well in 24-well plates and grown for $48 \mathrm{~h}$. The cells were then washed and cultured for $24 \mathrm{~h}$ in the medium without serum. Subsequently, $5 \mu \mathrm{g} / \mathrm{ml}$ of CTRP3/cartducin was added to the medium for 5, 15, 30, and $60 \mathrm{~min}$. For experiments with protein kinase inhibitor, cells were pretreated with U0126 for $1 \mathrm{~h}$ prior to CTRP3/cartducin treatment. In control experiments, $50 \mathrm{mM} \mathrm{NaH} \mathrm{PO}_{4}(\mathrm{pH}$ 8.0) containing $1 \mathrm{mM}$ EDTA and/or $0.4 \%$ dimethyl sulfoxide (DMSO) was added to the culture.

RT-PCR analysis. Total RNAs were extracted from cells using the RNeasy kit (Qiagen, Hilden, Germany). Total RNA $(2 \mu \mathrm{g})$ were reverse-transcribed using the Omniscript RT kit (Qiagen). After the RT reaction, 27 cycles of PCR were carried out as previously described (6). Primer sequences were: CTRP3/cartducin, 5'-GAAACAATGGGAACAAT GGAG-3' and 5'-TGCTGAAGGTGAAGAAATACA-3'; GAPDH, 5'-CCATCACCATCTTCCAGGAG-3' and 5'-GCA TGGACTGTGGTCATGAG-3'.

Measurement of DNA synthesis and cell number. To determine the growth-stimulatory effect of CTRP3/cartducin on NHOS or LM8 cells, bromodeoxyuridine (BrdU) assay was performed as described previously (7). In brief, the cells were seeded at a density of $1 \times 10^{4}$ cells/well in 96-well plates and grown for $24 \mathrm{~h}$. The medium was then replaced with RPMI-1640 or MEM containing $0.1 \%$ FCS for $24 \mathrm{~h}$. Subsequently, various concentrations of CTRP3/cartducin was added to the medium, incubated for $24 \mathrm{~h}$, and labeled with BrdU during the last $3 \mathrm{~h}$ of incubation.

Measurement of cell migration. The motility response of NHOS or LM8 cells to CTRP3/cartducin was assayed using a modified Boyden chamber technique. The cells were trypsinized, washed and resuspended in serum-free RPMI1640 or MEM containing $0.25 \%$ bovine serum albumin (BSA). The cell suspension $\left(100 \mu 1,5 \times 10^{4}\right.$ cells/well) was added to transwell inserts $(8.0-\mu \mathrm{m}$ pore size, Corning, Inc., Corning, NY) and the insert was then incubated for $2 \mathrm{~h}$ to
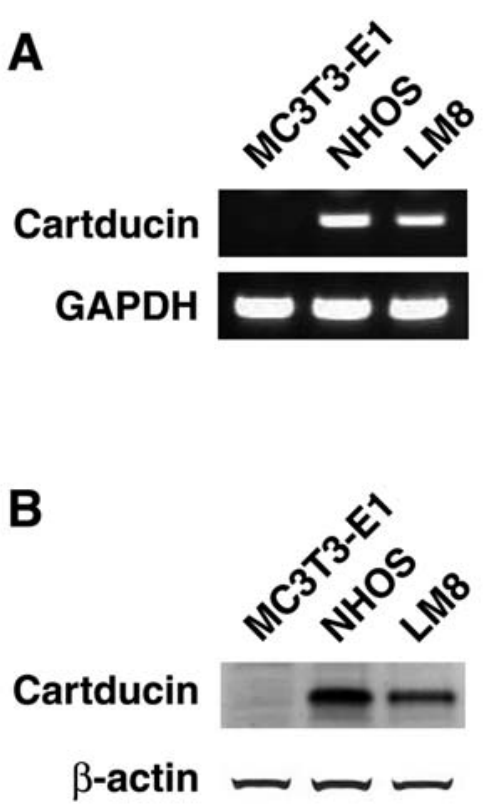

Figure 1. Expression of CTRP3/cartducin in mouse osteosarcoma cells. (A) RT-PCR analysis of CTRP3/cartducin mRNA expression in MC3T3-E1, NHOS and LM8 cells. Aliquots of PCR products were electrophoresed on a $2 \%$ agarose gel, and the gel was stained with ethidium bromide. CTRP3/ cartducin-specific bands were seen in NHOS and LM8 cells but not in MC3T3-E1 cells. PCR for GAPDH expression was also performed as a quality control. (B) Western blot analysis of CTRP3/cartducin protein expression in MC3T3-E1, NHOS and LM8 cells. A protein of identical molecular mass to CTRP3/cartducin can be detected in the total protein extracted from NHOS and LM8 cells but not from MC3T3-E1 cells. B-actin was used as an internal control.

allow cell attachment. Then, $500 \mu 1$ of serum-free RPMI1640 or MEM containing $0.25 \%$ BSA with or without the indicated concentrations of CTRP3/cartducin was added to the lower chamber and incubated for $5 \mathrm{~h}$. Non-migrating cells on the top of the membrane were removed by scraping and migrated cells on the lower surface of the membrane were fixed with ethanol and stained with hematoxylin. The number of cells migrating through the membrane was counted in five random fields per well under a microscope (magnification of $\mathrm{x} 400)$. All assays were performed in triplicate.

Western blot analysis. Protein immunoblotting was performed as previously described (8). Briefly, total cellular proteins were prepared by lysing cells in CelLytic lysis buffer (SigmaAldrich) containing protease inhibitor (Sigma-Aldrich) and phosphatase inhibitor (Sigma-Aldrich) cocktails, separated by SDS-PAGE, and transferred to PVDF membranes. The membranes were blocked for $30 \mathrm{~min}$ at room temperature and then incubated with first antibodies directed against CTRP3/ cartducin, ERK1/2, p-ERK1/2, and $\beta$-actin for $18 \mathrm{~h}$ at $4^{\circ} \mathrm{C}$. The detection of bound antibodies was performed using the WesternBreeze chromogenic detection system (Invitrogen, Carlsbad, CA) using alkaline phosphatase (AP)-conjugated donkey anti-goat IgG or donkey anti-rabbit IgG antibodies (Promega, Madison, WI).

Statistical analysis. The unpaired Student's t-test was used for statistical analysis of the experiments. Error bars represent $\mathrm{SD}$, and $\mathrm{p}<0.05$ was taken as the level of significance. 
A

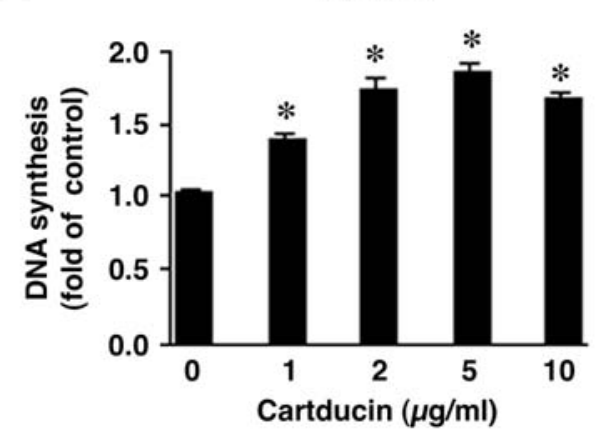

B

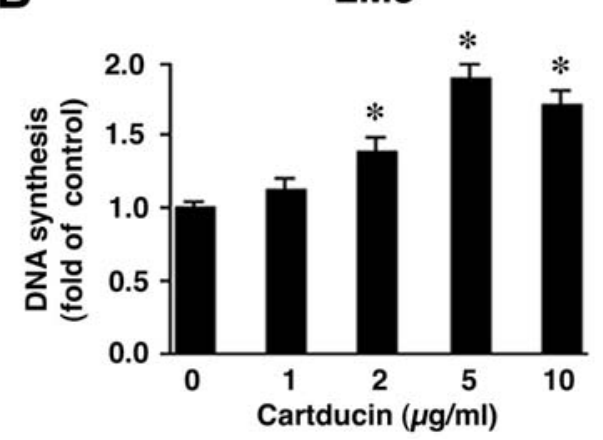

Figure 2. CTRP3/cartducin promotes the proliferation of osteosarcoma cells. (A) Effects of CTRP3/cartducin on DNA synthesis in NHOS cells. Cells were treated with the indicated concentrations of CTRP3/cartducin for $24 \mathrm{~h}$, and BrdU incorporation was measured. (B) Effects of CTRP3/cartducin on DNA synthesis in LM8 cells. Cells were treated with the indicated concentrations of CTRP3/cartducin for $24 \mathrm{~h}$. Data are the mean \pm SD of triplicate determinations. Similar results were obtained from two independent experiments. ${ }^{*} \mathrm{p}<0.05$.

\section{Results}

Expression of CTRP3/cartducin is increased in mouse osteosarcoma cells. To investigate whether CTRP3/cartducin expression levels are increased in osteosarcoma cells compared with their level in normal osteoblast cells, we first performed RT-PCR analysis. CTRP3/cartducin mRNA was detected in NHOS and LM8 cells but was undetectable in normal murine osteoblast MC3T3-E1 cells (Fig. 1A). We subsequently examined by Western blot analysis the expression of CTRP3/ cartducin protein in NHOS, LM8 and MC3T3 cells. CTRP3/ cartducin protein was detected in NHOS and LM8 cells but was undetectable in MC3T3-E1 cells (Fig. 1B). These results suggest that elevated CTRP3/cartducin expression might be involved in osteosarcoma pathogenesis and metastasis.

CTRP3/cartducin promotes proliferation of osteosarcoma cells. To investigate whether CTRP3/cartducin has a role in osteosarcoma tumor growth, we next examined the effect of CTRP3/cartducin on the proliferation of NHOS and LM8 cells. A dose-dependent increase in BrdU incorporation into the DNA was observed in NHOS cells. Maximum stimulation in DNA synthesis occurred in the presence of $5 \mu \mathrm{g} / \mathrm{ml}$ of CTRP3/cartducin (1.8-fold when compared with controls, $\mathrm{p}<0.05$ ) (Fig. 2A). Similarly, a dose-dependent increase in
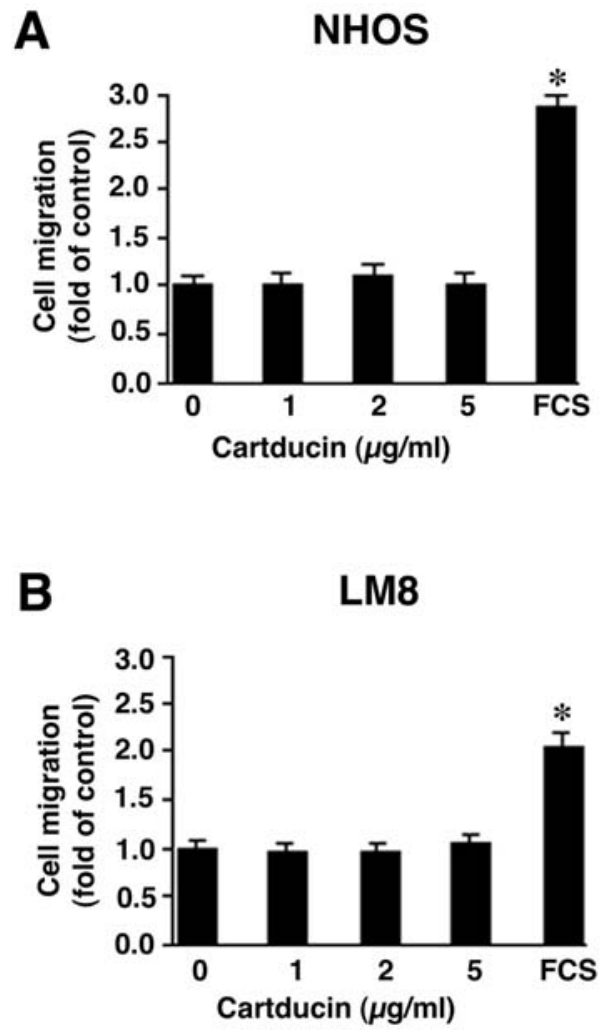

Figure 3. The effect of CTRP3/cartducin on the migration of osteosarcoma cells. (A) NHOS cells were treated with the indicated concentrations of CTRP3/cartducin for $5 \mathrm{~h}$, and the motility response of the cells to CTRP3/ cartducin was assayed by a modified Boyden chamber technique. (B) LM8 cells were treated with the indicated concentrations of CTRP3/cartducin for $5 \mathrm{~h}$, and the motility response of the cells to CTRP3/cartducin was assayed. Data are the mean \pm SD of triplicate determinations. Similar results were obtained from two independent experiments. FCS (10\%) was used as positive control. ${ }^{*} \mathrm{p}<0.05$.

BrdU incorporation into the DNA was observed in LM8 cells (1.9-fold when compared with controls, p<0.05) (Fig. 2B). These results indicate that CTRP3/cartducin promotes the proliferation of osteosarcoma cells.

The effect of CTRP3/cartducin on the migration of osteosarcoma cells. Since increased tumor cell migration is important in metastasis, we next examined whether CTRP3/ cartducin could affect osteosarcoma cell migration. Cell migration was analyzed by a modified Boyden chamber technique. However, CTRP3/cartducin had no significant effects on the migration of NHOS and LM8 cells (Fig. 3A and $\mathrm{B})$.

CTRP3/cartducin activates ERK1/2 pathway in osteosarcoma cells. MAPK and PI3K/Akt pathways respond to mitogenic factors; therefore, we analyzed the effects of CTRP3/cartducin on the phosphorylation of three groups of MAPKs, such as ERK, c-jun N-terminal kinase (JNK), and p38 MAPK, or Akt in NHOS and LM8 cells. Western blot analysis detected increased ERK1/2 phosphorylation in NHOS cells treated with $5 \mu \mathrm{g} / \mathrm{ml}$ of CTRP3/cartducin after $5 \mathrm{~min}$, with the maximal increase occurring after $15 \mathrm{~min}$ of treatment and decreasing after $1 \mathrm{~h}$ (Fig. 4A). Similarly, increased ERK1/2 phosphorylation was also detected after $15 \mathrm{~min}$, decreasing 
A

\section{NHOS}

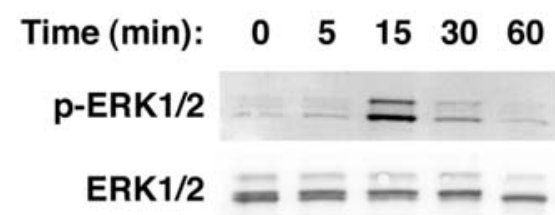

B
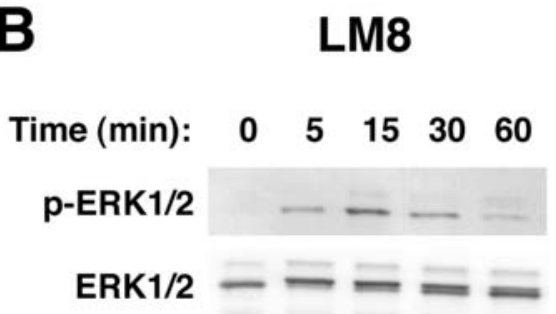

Figure 4. Effects of CTRP3/cartducin on activation of the ERK1/2 signaling pathway in osteosarcoma cells. (A) Subconfluent cultures of NHOS cells stimulated with $5 \mu \mathrm{g} / \mathrm{ml}$ of CTRP3/cartducin for the indicated times were analyzed by Western blotting for phosphorylated ERK1/2 (p-ERK1/2) and total ERK1/2. (B) Subconfluent cultures of LM8 cells stimulated with $5 \mu \mathrm{g} /$ $\mathrm{ml}$ of CTRP3/cartducin for the indicated times were analyzed for phosphorylated ERK1/2 (p-ERK1/2) and total ERK1/2.

after $1 \mathrm{~h}$ (Fig. 4B). In contrast, CTRP3/cartducin had no effect on the activities of p38 MAPK, JNK1/2 and Akt, and none of their phosphorylated forms were detected (data not shown).

ERK1/2 pathway is involved in CTRP3/cartducin-induced proliferation of osteosarcoma cells. Since Western blot analysis confirmed CTRP3/cartducin-induced ERK1/2 pathway activation in NHOS and LM8 cells, we next determined whether CTRP3/cartducin-induced osteosarcoma cell proliferation is mediated through activation of this pathway. ERK1/2 has been shown to be activated by their upstream activators, MEK1/2. NHOS or LM8 cells were pretreated with the MEK1/2 inhibitor U0126 for $1 \mathrm{~h}$ before and the duration of the stimulation, and DNA synthesis analysis was performed. U0126 alone had no effect on proliferation, and no toxicity at the concentration used was observed. Inhibition of the ERK1/2 pathway by pretreatment with U0126 significantly reduced DNA synthesis in NHOS cells in a dose-dependent manner after CTRP3/cartducin stimulation (Fig. 5A). Similarly, inhibition of the ERK1/2 pathway by pretreatment with U0126 led to a block of CTRP3/cartducin-induced LM8 cell proliferation (Fig. 5B). These results suggest the involvement of the ERK1/2 pathway in the ability of CTRP3/cartducin to stimulate proliferation of osteosarcoma cells.

\section{Discussion}

CTRP3/cartducin is a newly discovered cartilage-derived skeletal growth factor (6), and has been indicated to play important roles in regulating both embryonic cartilage development and postnatal longitudinal bone growth by directly promoting the proliferation of mesenchymal chondroprogenitor cells and chondrocytes (7). It has been reported
A

NHOS

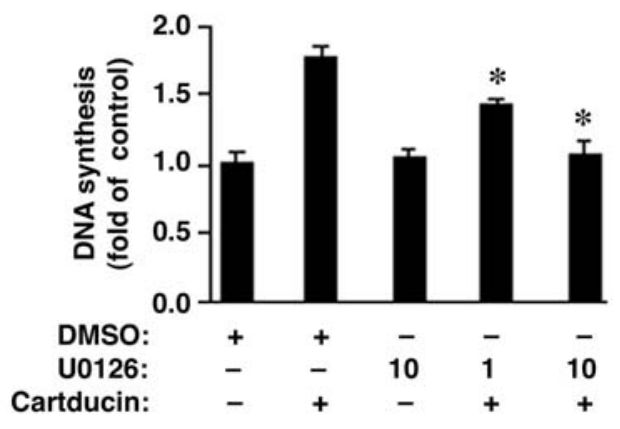

B

LM8

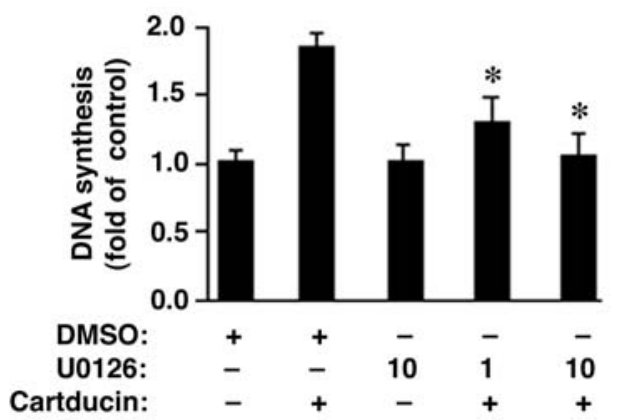

Figure 5. Effects of MEK1/2 inhibitor on the proliferation of osteosarcoma cells. (A) Subconfluent cultures of NHOS cells were serum-starved and preincubated with the indicated concentrations $(1-10 \mu \mathrm{M})$ of U0126 for $1 \mathrm{~h}$ before CTRP3/cartducin treatment $(5 \mu \mathrm{g} / \mathrm{ml})$, and BrdU incorporation was measured. (B) Subconfluent cultures of LM8 cells were serum-starved and preincubated with the indicated concentrations (1-10 $\mu \mathrm{M})$ of U0126 for $1 \mathrm{~h}$ before CTRP3/cartducin treatment $(5 \mu \mathrm{g} / \mathrm{ml})$, and BrdU incorporation was measured. Data are the mean \pm SD of triplicate determinations. Similar results were obtained from two independent experiments. ${ }^{*} \mathrm{p}<0.05$ versus CTRP3/cartducin-treated vehicle control.

that CTRP3/cartducin is expressed in osteosarcoma (14); however, its role in bone tumor development has not been explored.

In this study, we examined the roles of CTRP3/cartducin in osteosarcoma by using murine osteosarcoma cell lines, NHOS and LM8, as a model. NHOS cells, which form primary bone tumors, were established from a spontaneous soft tissue tumor in a BALB/c mouse (15), and LM8 cells were established from Dunn's osteosarcoma (16). Although MC3T3-E1 normal murine osteoblasts expressed little to no CTRP3/cartducin mRNA and protein, both murine osteosarcoma cell lines, NHOS and LM8, expressed CTRP3/ cartducin. Up-regulated CTRP3/cartducin expression may therefore play a role in tumor growth and metastasis. In order to investigate the direct effect of CTRP3/cartducin on osteosarcoma proliferation and migration, recombinant CTRP3/ cartducin was used. Stimulation with CTRP3/cartducin promotes proliferation in both NHOS and LM8 cells in a dosedependent manner; however, CTRP3/cartducin had no effect on migration in these two osteosarcoma cell lines. These results suggest that CTRP3/cartducin may play a role in osteosarcoma tumor growth. 
In contrast to adiponectin (17), no CTRP3/cartducinspecific receptor has yet been identified and cloned. Although MAPKs or phosphatidylinositol 3-kinase (PI3K)/Akt pathways are known to be activated by CTRP3/cartducin stimulation in mesenchymal chondroprogenitor cells or endothelial cells $(8,9)$, little is known about its signaling pathways in tumor cells. To gain insight into the mechanisms by which CTRP3/ cartducin promotes the proliferation of osteosarcoma cells, we evaluated the signaling events. MAPKs and PI3K/Akt pathways are well known to play an essential role in controlling cell proliferation in response to growth factors and other signals (18-20). Osteosarcoma tumor growth is the result of a very complex network of intracellular signaling systems, and both MAPKs and PI3K/Akt pathways are critical regulators of the proliferation and survival of osteosarcoma cells $(21,22)$.

In this study, we found that the ERK1/2 signaling pathway was activated in CTRP3/cartducin-treated NHOS and LM8 cells. Using a specific kinase inhibitor, we were able to study the role of this signaling pathway and dissected the pathway leading to proliferation in these cells. CTRP3/cartducininduced DNA synthesis of these two osteosarcoma cell lines was inhibited by U0126, suggesting that the ERK1/2 pathway is required for CTRP3/cartducin-induced proliferation of osteosarcoma cells.

In summary, we demonstrated that CTRP3/cartducin expression is increased in two murine osteosarcoma cell lines compared with its level in normal murine osteoblasts. CTRP3/ cartducin positively regulates the proliferation of osteosarcoma cells via the MAPK signaling pathway. These results suggest that CTRP3/cartducin may play an important role in the progression of osteosarcoma.

\section{Acknowledgements}

This study was supported by Grants-in-aid for Scientific Research (No. 20592197) and the 21st Century Center of Excellence Program from the Ministry of Education, Culture, Sports, Science and Technology of Japan.

\section{References}

1. Jaffe N, Carrasco H, Raymond K, Ayala A and Eftekhari F: Can cure in patients with osteosarcoma be achieved exclusively with chemotherapy and abrogation of surgery? Cancer 10: 2202-2210 2002.

2. Kishore U, Gaboriaud C, Waters P, Shrive AK, Greenhough TJ, Reid KBM, Sim RB and Arlaud GJ: C1q and tumor necrosis factor superfamily: modularity and versatility. Trends Immunol 25: 551-561, 2004.

3. Wong GW, Wang J, Hug C, Tsao TS and Lodish HF: A family of Acrp30/adiponectin structural and functional paralogs: Proc Natl Acad Sci USA 101: 10302-10307, 2004.

4. Lasser G, Guchhait P, Ellsworth JL, Sheppard P, Lewis K, Bishop P, Cruz MA, Lopez JA and Fruebis J: C1qTNF-related protein-1 (CTRP-1): a vascular wall protein that inhibits collagen-induced platelet aggregation by blocking VWF binding to collagen. Blood 107: 423-430, 2006
5. Mandal MN, Vasireddy V, Reddy GB, Wang X, Moroi SE, Pattnaik BR, Hughes BA, Heckenlively JR, Hitchcock PF, Jablonski MM and Ayyagari R: CTRP5 is a membrane-associated and secretory protein in the RPE and ciliary body and the S163R mutation of CTRP5 impairs its secretion. Invest Opthal Vis Sci 47: 5505-5513, 2006.

6. Maeda T, Abe M, Kurisu K, Jikko A and Furukawa S: Molecular cloning and characterization of a novel gene, CORS26, encoding a putative secretory protein and its possible involvement in skeletal development. J Biol Chem 276: 3628-3634, 2001.

7. Maeda T, Jikko A, Abe M, Yokohama-Tamaki T, Akiyama H, Furukawa S, Takigawa $\mathrm{M}$ and Wakisaka S: Cartducin, a paralog of Acrp30/adiponectin is induced during chondrogenic differentiation and promotes proliferation of chondrogenic precursors and chondrocytes. J Cell Physiol 206: 537-544, 2006.

8. Akiyama H, Furukawa S, Wakisaka S and Maeda T: Cartducin stimulates mesenchymal chondroprogenitor cell proliferation through both extracellular signal-regulated kinase and phosphatidylinositol 3-kinase/Akt pathways. FEBS J 273: 2257-2263, 2006.

9. Li JM, Zhang X, Nelson PR, Odgren PR, Nelson JD, Vasiliu C, Park J, Morris M, Lian J, Cutler BS and Newburger PE: Temporal evolution of gene expression in rat carotid artery following balloon angioplasty. J Cell Biochem 101: 399-410, 2007.

10. Akiyama H, Furukawa S, Wakisaka S and Maeda T: CTRP3/ cartducin promotes proliferation and migration of endothelial cells. Mol Cell Biochem 304: 243-248, 2007.

11. Dvorak HF: Tumors: wounds that do not heal. Similarities between tumor stroma generation and wound healing. N Engl J Med 315: 1650-1659, 1986.

12. Coussens LM and Werb Z: Inflammation and cancer. Nature 420: 860-867, 2002.

13. Beachy PA, Karhadkar SS and Berman DM: Tissue repair and stem cell renewal in carcinogenesis. Nature 432: 324-331, 2004.

14. Schaffler A, Ehling A, Neumann E, Herfarth H, Paul G, Tarner I, Gay S, Scholmerich J and Muller-Ladner U: Genomic organization, promoter, amino acid sequence, chromosomal localization, and expression of the human gene for CORS-26 (collagenous repeat-containing sequence of $26-\mathrm{kDa}$ protein). Biochym Biophys Acta 1630: 123-129, 2003.

15. Kusumi T, Nishi T, Tanaka M, Tsuchida S and Kudo H: A murine osteosarcoma cell line with a potential to develop ossification upon transplantation. Jpn J Cancer Res 92: 649-658, 2001.

16. Asai T, Ueda T, Itoh K, Yoshioka K, Aoki Y, Mori S and Yoshikawa $\mathrm{H}$ : Establishment and characterization of a murine osteosarcoma cell line (LM8) with highly metastatic potential to the lung. Int J Cancer 76: 418-422, 1998.

17. Yamauchi T, Kamon J, Ito Y, Tsuchida A, Yokomizo T, Kita S, Sugiyama T, Miyagishi M, Hara K, Tsunoda M, Murakami K, Ohteki T, Uchida S, Takekawa S, Waki H, Tsuno NH, Shibata Y, Terauchi Y, Froguel P, Tobe K, Koyasu S, Taira K, Kitamura T, Shimizu T, Nagai R and Kadowaki T: Cloning of adiponectin receptors that mediate antidiabetic metabolic effects. Nature 423: 762-769, 2003.

18. Hill CS and Treisman R: Transcriptional regulation by extracellular signals: mechanisms and specificity. Cell 80: 199-211, 1995.

19. Seger R and Krebs EG: The MAPK signaling cascade. FASEB J 9: 726-735, 1995.

20. Lawlor MA and Alessi DR: PKB/Akt: a key mediator of cell proliferation, survival and insulin responses? J Cell Sci 114: 2903-2910, 2001.

21. Coltella N, Manara MC, Cerisano V, Trusolino L, Di Renzo MF Scotlandi K and Ferracini R: Role of the METHGF receptor in proliferation and invasive behavior of osteosarcoma. FASEB J 17: 1162-1164, 2003.

22. Bentov I, LeRoith D and Werner H: The WT1 Wilms' tumor suppressor gene: a novel target for insulin-like growth factor-I action. Endocrinology 144: 4276-4279, 2003. 